\title{
Después de veinte años, ipobre Bolonia!
}

\author{
Jordi PALÉS-ARGULLÓS
}

El año 1999 vio la luz la 'Declaración de Bolonia', que fijó el marco en el que había de desarrollarse la educación superior en Europa. Sus objetivos declarados eran fijar un sistema de titulaciones comparables y comprensivas, adoptar un sistema basado en dos principales ciclos (graduado y posgraduado), implementar un sistema común de créditos, promover la movilidad (de estudiantes, profesores, investigadores y personal de administración) y facilitar la cooperación europea para asegurar la calidad con el objetivo de desarrollar criterios y metodologías comparables. Sin embargo, subyacían otros principios, otros aspectos, quizás tanto o más relevantes: la declaración focalizó la educación centrada en quien aprende, la educación orientada a las competencias, y apuntó como diana los procesos de evaluación en general y los de las competencias en particular.

Hoy, todas las facultades de medicina españolas tienen sus planes de estudios adaptados a Bolonia; han egresado diferentes promociones y muchas de ellas han renovado su acreditación por la ANECA (Agencia Nacional de Evaluación de la Calidad y Acreditación) o por la agencia de calidad autonómica respectiva.

En un editorial [1] de FEM de 2016 se planteaban diferentes preguntas como base para una reflexión sobre el desarrollo del proceso de Bolonia en nuestras facultades. Este editorial retoma algunos de los puntos de aquel posicionamiento y, en especial, que los currículos o planes de estudio no son entes inmutables. Su revisión ni siquiera debe ser periódica, sino permanente. De hecho, los procesos de reacreditación deberían servir precisamente para evaluar cómo han funcionado en un período determinado y, en base a dicha evaluación, promover cambios para su mejora. No olvidemos que uno de los objetivos de Bolonia es la mejora de la calidad y esto debe realizarse necesariamente a través de evaluaciones que permitan la renovación de la acreditación.

\section{Twenty years on, poor Bologna!}

The year 1999 saw the birth of the 'Bologna Declaration, which set the framework within which higher education was to develop in Europe. Its stated objectives were to establish a system of comparable and comprehensive degrees, to adopt a system based on two main cycles (graduate and postgraduate), to implement a common system of credits, to promote mobility (of students, lecturers, researchers and administrative staff) and to facilitate European cooperation in order to ensure quality with the aim of developing comparable criteria and methodologies. Yet, underlying the process there were other principles, other aspects, that were perhaps equally or more relevant: the declaration was focused on learnercentred education, competence-oriented education and targeted assessment processes in general and those involving competencies in particular.

Today, all Spanish faculties of medicine have their curricula adapted to Bologna. Different promotions have graduated from them and many have had their accreditation renewed by the ANECA (Spanish Agency for Quality Assessment and Accreditation) or by the respective autonomous quality agency.

In an editorial published by FEM in 2016 [1] a series of questions were posed as the basis for a reflection on the development of the Bologna process in our faculties. This editorial takes up some of the points from that standpoint and, more specifically, the idea that curricula are not immutable entities. They should not be reviewed periodically but instead on a permanent basis. In fact, re-accreditation processes should serve precisely to assess how they have worked in a given period of time and, based on that assessment, to promote changes aimed at improving them. Let us not forget that one of the aims of Bologna is to improve quality and this must necessarily be carried out through assessments that allow for the renewal of accreditation.

Have any suggestions been made to introduce any significant modifications in the curricula that were initially proposed? Have any new competencies or
Fundación Educación Médica.

E-mail:

jpales@ub.edu

(c) 2019 FEM 
¿Se han propuesto modificaciones importantes a las propuestas iniciales de los currículos? ¿Se han planteado nuevas competencias o nuevos contenidos acordes con los avances científicos y metodológicos? ¿Se ha avanzado hacia programas formativos con carácter más integrado? ¿Se ha progresado en el desarrollo y evaluación de las competencias transversales, profesionalismo, bioética, trabajo en equipo, formación en metodología de la investigación, razonamiento clínico, formación para el aprendizaje a lo largo de la vida, economía de la salud, etc.? ¿Son las metodologías activas centradas en el estudiante las que presiden nuestros currículos?

Si en algo se ponía el acento en el editorial de 2016 era el tema de la evaluación de las competencias y los instrumentos adecuados para ello. La clave, el cambio de paradigma, reside en pasar de una evaluación puntual y delimitada, de una evaluación estanca, a otra global, dilatada en el tiempo y, en cualquier caso, multimedia. En lugar de evaluaciones puntuales, debemos establecer programas comprensivos de evaluación de las competencias, de múltiples aspectos parciales.

Mayoritariamente, en las facultades de medicina, cada materia sigue evaluando a sus estudiantes como considera más adecuado. Superadas todas las materias del plan de estudios, un alumno se gradúa. Esto no es Bolonia. ¿Estamos seguros de que un alumno que haya superado de forma independiente las asignaturas tiene todas las competencias previstas en el plan de estudios? Es verdad que todas las facultades de medicina han desarrollado e implementado una evaluación clínica objetiva estructurada (ECOE) que evalúa competencias y ha de reconocerse el esfuerzo de la Conferencia de Decanos en desarrollar, en sus respectivas facultades, dicha evaluación, pero las ECOE nacieron hace más de cuarenta años y la investigación en evaluación en educación médica ha aportado nuevos paradigmas y nuevos instrumentos de evaluación.

Insistamos: ¿un alumno que supere la ECOE al final del rotatorio tiene todas las competencias previstas en el programa formativo? Imposible asegurarlo. ¿Se han implementado medidas de remediación de los alumnos (si hay alguno) que no la superan? La ECOE, prueba con un gran impacto educativo, es un instrumento válido, pero solo uno más; la ECOE no basta. Hay instrumentos válidos, fiables y más sencillos y económicos (el mini-CEX sería un buen ejemplo) que permiten una evaluación más continua y progresiva y, sobre todo, facilitan el feedback con el alumno. Esto último es muy impor- new contents been considered in keeping with the latest scientific and methodological advances? Has any progress been made towards more integrated training programmes? Has any progress been made in the development and assessment of cross-cutting competencies, professionalism, bioethics, teamwork, training in research methodology, clinical reasoning, training in lifelong learning, health economics, and so on? Are active, student-centred methodologies at the heart of our curricula?

If anything was emphasised in the 2016 editorial, it was the subject of the assessment of competencies and the appropriate instruments with which to carry it out. The key, the paradigm shift, lies in moving from a sporadic delimited assessment, from a hermetic evaluation, to a global one that is prolonged in time and, in any case, multimedia. Rather than sporadic assessments, we must establish comprehensive programmes for the evaluation of competencies and of a multitude of other partial aspects.

In the majority of cases, in faculties of medicine each subject continues to assess its students as it deems most appropriate. Once all the subjects on the curriculum have been passed, a student graduates. This is not what Bologna is about. Can we be sure that a student who has passed the subjects independently has all the competencies set out in the curriculum? It is true that all faculties of medicine have developed and implemented an objective structured clinical evaluation (OSCE) that assesses competencies, and the efforts made by the Conference of Deans to develop this evaluation, in their respective faculties, must be acknowledged, but the OSCEs came into being more than forty years ago and research on assessment in medical education has given rise to new paradigms and new evaluation instruments.

Again: does a student who passes the OSCE at the end of rotation have all the competencies foreseen in the training programme? Impossible to say for sure. Have any remediation measures been implemented for students (if any) who do not pass? The OSCE, a test with a high educational impact, is a valid instrument, but it is just one more; the OSCE alone is not enough. There are valid, reliable instruments that are simpler and cheaper (the mini-CEX would be a good example) which allow for a more continuous and progressive assessment and, above all, which facilitate feedback with the student. The latter is very important because it is what makes it possible to move from the concept of the assessment 'of' learning to that of assessment 'for' learning [2]. We must stop thinking in terms of 'single moments of assessment' and move on to 'multiple moments of assessment'; assessment must shift from being single 
tante porque es lo que permite pasar del concepto de evaluación 'del' aprendizaje al concepto de evaluación 'para' el aprendizaje [2]. Hay que dejar de pensar en términos de 'momentos únicos de evaluación' y pasar a 'momentos múltiples de evaluación'; la evaluación debe pasar de única a progresiva a lo largo de todo el proceso formativo. La evaluación debe dejar de ser del profesor y ser de la institución, dejar de ser un examen y convertirse en un programa de evaluación.

Estas breves líneas han intentado repasar, con conciencia crítica, lo que hace veinte años pidió Bolonia y a dónde hemos llegado. ¿Lo estamos haciendo bien? ¿Podríamos hacerlo mejor? to progressive throughout the whole formative process. Assessment must stop belonging to the teacher and the institution, that is, it must cease to be an exam, and become an assessment programme.

These brief lines have attempted to review, with a critical spirit, what Bologna asked for twenty years ago and how far we have come since then. Are we doing it right? Could we do it better?

Bibliografía / References

1. Palés-Argullós J. Bolonia en las facultades de medicina españolas, seis años después: algunas preguntas para la reflexión. FEM 2016; 19: 109-11.

2. Van der Vleuten C, Heeneman S. A new holistic way of assessment: programmatic assessment. FEM 2016; 19: 275-9. 
